\title{
ПЕРЕВОД ЛЕКСИЧЕСКИХ ЕДИНИЦ ТЕМАТИЧЕСКОЙ ГРУППЫ «ОДЕЖДА» С РУССКОГО НА АНГЛИЙСКИЙ ЯЗЫК В ПОЭМЕ Н.В. ГОГОЛЯ «МЕРТВЫЕ ДУШИ»
}

На материале поэмы Н.В.Гоголя «Мертвые души» и ее перевода на английский язык рассмотрены лексические единицы, входяшие в состав лексико-тематической группь "Одежда». Обращается внимание на перевод одинаковых названий одежды в разных эпизодах произведения, их художественнье функичи и некоторые другие особенности перевода устаревщей лексики русского языка.

Ключевые слова: лексема, перевод, тематическая группа, устаревщая лексика, сопоставительный анализ.

On the basis of N.V. Gogol's poem "Dead Souls" and its translation into English, the author considers lexical units that are part of the thematic group "Clothes". Attention is drawn to the translation of the same names of clothes in different episodes of the poem, their artistic functions and some other features of the translation of the outdated vocabulary of the Russian language.

Key words: lexeme, translation, thematic group, outdated vocabulary, comparative analysis.

В русском языке имеются целые пласты слов, которые характеризуются лингвистами как архаичные, поэтому переводчику необходимо владеть большим запасом лексики как на русском, так и на английском языках, обладать как лингвистическими навыками и компетенциями, так и существенным запасом экстралингвистических фоновых знаний для того, чтобы решить проблему перевода подобных лексем. Кроме того, «Понимание текста часто усложняется временным, культурным и языковым разрывом между автором текста и его интерпретатором, который в нашем случае выступает в роли переводчика». [Морозкина 2014: 86]. 
Цель данной статьи - рассмотреть и изучить научные взгляды на художественный перевод, проанализировать способы перевода лексических единиц с национальнокультурным компонентом с русского на английский язык. Задачи исследования включают: анализ оригинального текста и текста перевода с точки зрения адекватной передачи лексем, входящих в тематическую группу «Одежда», выявление спорных моментов в текстах переводов. Предметом данного исследования являются особенности перевода лексем определенной тематической группы с русского на английский язык. Объектом исследования служат лексические единицы из произведения «Мертвые души» (1841 г.) Николая Васильевича Гоголя и перевод на английский язык, выполненный Чарльзом Джеймсом Хогартом (1915 г.). В процессе анализа были использованы следующие методы исследов ания: общ ен аучные методы анализа и си нтеза, метод словарных дефиниций; метод сплошной выборки, метод сопоставительного анализа; метод контент-анализа и метод систематизации.

Художественный перевод предполагает «творческое преобразование литературного подлинника не только в соответствии с литературными нормами, но и с использованием всех необходимых выразительных возможностей переводящего языка, сопровождаемого культурологически оправданной трансформацией литературных особенностей оригинала и той эмоциональноэстети ческой информации, которая присуща подлиннику как вт оричной знаков ой си ст еме». [Каза кова 2006:10] Переводчику придется приобрести необходимые знания об эпохе, в которую жил и творил русский писатель, то есть иметь необходимые фоновые, функциональные, социально-бытовые знания, чтобы точно использовать лексику ограниченного употребления, которая почти не встречается в современном русском языке. Задачу усложняет тот факт, что в произведении «Мертвые души» бытовые предметы выполн яют не только оп исательную функцию, но и выступают в качестве выразительного средства создания образа, формируют представление о личностных характеристиках персонажа, которому он и принадлежат. 
Используя метод сплошной выборки, был составлен лексико-тематический ряд, включающий в себя единицы, называющие предметы одежды.

Армяк "rough cloak" - архалук "coat of striped pattern/overcoat" - венгерка "dark-blue coat" - капот "highnecked morning dress" - картуз "cap" - кафтан "coat" - клок "cloak" - ливрея "livery" - мундир "uniform" - панталоны "breeches" - роброн "опущено в переводе" - рубаха "clothes" сюртук "tailcoat/ jacket/ frockcoat" - тулуп "large overcoat/ sheepskin jacket" - ночной чепец "night cap" - фрак "frockcoats/ black coats" - халат "dressing-gown" - шинель "cloak/ greatcoat/ overcoat"

Анализируя представленный лексико-семантический ряд, делаем вывод, что некоторые лексемы использовались в произведении несколько раз, при этом переводчик не сохранял единообразие в тексте переводе, меняя вариант эквивалента. Кроме того, некоторые лексические единицы были опущены в переводе, что представляет собой серьезную переводческую проблему, поскольку при опущении «значительный пласт информации может оказаться утерянным для реципиента» [Морозкина 2018: 541], что может в значительной степени отразиться на «понимании смысла художественного текста» [Морозкина 2020: 158].

«Чемодан внесли кучер Селифан, низенький человек в тулупчике, и лакей Петрушка, малый лет тридцати, в просторном подержанном сюртуке, как видно с барского плеча...» [Гоголь 1975:316] “Т "The bearers of the same were the gentlemen's valet Petruchka - the latter a fellow of about thirty, clad in a worn, over-ample jacket which formerly had graced his master's shoulders" [Gogol 2003: 12]

Согласно словарю русского языка, «Тулуп - длинная, обычно не крытая сукном меховая шуба без перехвата с высоким воротником. Тулупчик - уменьшительноласкательное от тулуп, короткий маленький тулуп». [Евгеньева 1999: 424] «Сюртук - мужская верхняя двубортная одежда в талию с длинным полями». [Евгеньева 1999: 328] Лексема «тулупчик» была передана на английский язык как "overcoat" «теплое тяжелое пальто, которое надевают на другую одежду и носят в холодную погоду». [Collins 1995: 
1111] В данном эквиваленте есть сема «теплая одежда», но не акцентируется внимание на главном признаке тулупа высоком воротнике. Таким образом, в тексте перевода прослеживается сдвиг в сторону признака «теплый». Кроме того, Суффикс «чик» является формообразовательной единицей, выражающей оценку предмету или лица и придает уменьшительно-ласкательное значение. Данная морфемная ос обенность в переводе была утрачена.

В качестве перевода лексемы «сюртук» использовался вариант "jacket" «короткая верхняя одежда с рукавами и застежкой спереди». [Collins 1995: 823] Данная лексема соответствует русской лексема «куртка». Однако в другом эпизоде поэмы, данная лексема была передана как "tailcoat", «мужской пиджак черного цвета, с вырезанными спереди полями, который является частью парадного вечернего костюма». [Collins 1995: 1527] В русском языке данная лексическая единица соответствует лексеме «фрак». И если в первом случае мы наблюдаем семантический сдвиг, то во втором случае мы можем говорить о явном нарушении в передаче смыслового содержания текса оригинала.

«Молодой человек оборотился назад, посмотрел экипаж, придержал рукою картуз, чуть не слетевший от ветра, и пошел своей дорогой». [Гоголь 1975: 315] “The young man turned his head as he passed the britchka and eyed it attentively; after which he clapped his hand to his cap (which was in the danger of being removed) and resumed his way". [Gogol 2003: 5]

«Куртуз - мужской головной убор с козырьком». [Евгеньева1999: 36] Лексема “сар” имеет гораздо более широкий спектр значений: кепка, шапка, фуражка и т.д. Тем не менее, это единственно возможный вариант передачи данной лексической единицы.

При отборе языков ого материла мы обратили внимание на то, что Гоголь для названия разновидностей одежды применяет приём метонимизации между предметом и материалом из которого он сделан. Таким образом, перечень изучаемой тематической группы был расширен.

«Не успел он выйти на улицу, размышляя обо всем этом и в то же время таща на плечах медведя, крытого коричневым сукном ...» [Гоголь 1975: 412] "P ulling on his cinnamon-coloured, 
bear-lined overcoat as he went, he had just stepped thoughtfully in to the street..." [Gogol 2003: 31]

В данном случае, переводчик использовал стратегию описательного перевода, не сохранив при этом троп переносного употреблен ия.

Сумм ируя данные проведенного анализа, можно сделать вывод о том, что вариантные соответствия, представленные в переводе Ч.Дж.Хогарта, не отображают в полной мере национально-культурную информацию, содержащуюся в русских лексемах. В переводе допускаются неоправданные семантические и лексические модификации, в некоторых случаях нарушается смысловое содержание текста оригинала. Переводчик не придерживается единообразия при передаче национально-культурных компонентов. Это свидетельствует о том, что переводчик видел свою задачу в переводе понятийного содержания, но не в передаче реалий, присущих национальной культуре. Кроме того, для названия одежды писатель не ограничивается прямыми обозначениями, что осложняет работу переводчика.

Проведенное исследование перевода лексических единиц ограниченного употребления выявляет значительные сложности художественного перевода. Эти и другие аспекты функционирования лексико-тематического ряда могут стать материалом последующих исследований.

\section{ЛИТЕРАТУРА}

1. Гоголь Н.В. Повести. Пьесы. Мертвые души. М., 1975.

2. Казакова Т.А. Художественный перевод: в поисках истины. СПб., 2006.

3. Морозкина Е.А., Алтынгужин Т.Р., Моделирование «внугреннеговнешнего» в семиотическом художественном пространстве текста (на материале романа ДТартт «Щегол») // Вестник Баш. ун-та. 2020. Т. 25. №1. C.159

4. Морозкина Е. А., Биктимирова М. М., Исхакова Э. В. Библейская метафора в художественном тексте// Вестник Баш. ун-та. 2018. Т. 23. №2. С. $541 .$.

5. Морозкина Е. А., Насанбаева Э.Р. Отражение национальной языковой картины мира в герменевтическом круге в процессе перевода. Уфа: РИЦ БашГУ, 2014. С.84.

6. Словарь русского языка: в 4т/под ред. А.П. Евгеньевой. М., 1999.

7. Collins EnglishDictionary.L., 1995.

8. Gogol N. Dead Souls/translated by D/J/Hogarth. N.Y., 2003.

СЮсупова 3.Р.,2021 г. 